\title{
Perianal comedones: a benign and rarely documented entity
}

\author{
Alicia Dimech, ${ }^{1}$ Liam Mercieca, ${ }^{2}$ Lawrence Scerri ${ }^{2}$
}

${ }^{1}$ Department of Medicine, Mater Dei Hospital, Msida, Malta ${ }^{2}$ Department of Dermatology \& Venereology, Sir Paul Boffa Hospital, Floriana, Malta

\section{Correspondence to}

Dr Alicia Dimech;

dimech.alicia@gmail.com

Accepted 17 April 2020

\section{DESCRIPTION}

A 66-year-old man presented to a dermatology outpatient clinic for assessment of perianal lesions noted incidentally during a screening colonoscopy, undertaken in view of a strong family history of colon adenocarcinoma. His medical history includes hypertension and hypothyroidism controlled with amlodipine and levothyroxine, respectively. He has no personal or family history of skin cancer or any relevant skin conditions. The patient denied any associated perianal symptoms, including pruritus or pain, or any gastrointestinal symptoms. No topical treatment was ever applied to the affected area. No relevant sexual history or occupational exposures were documented. On examination, he had multiple perianal papules with plugged follicular orifices consistent with comedones (figure 1). No such lesions were noted on the face, axillae, groins, neck or shoulders.

Comedones form due to pilosebaceous ductal hyperkeratinisation. ${ }^{1}$ Proliferation of keratinocytes within the duct results in occlusion of sebaceous secretions and accumulation of an abnormally high amount of sebaceous lipids. ${ }^{1}$ Comedone formation is likely multifactorial. ${ }^{2}$ Postulated contributory factors include abnormal levels of lipids such as linoleate and squalene, the proinflammatory cytokine interleukin-1 alpha, leptin, vitamin A deficiency, bacteria and ingredients in skin care products such as cocoa butter and esters. $^{1}$

Comedones are commonly reported in acne vulgaris, hidradenitis suppurativa, FavreRacouchot syndrome, Apert syndrome and nevus comedonicus, and rarely reported in other conditions such as folliculotropic mycosis fungoides, Birt-Hogg-Dube syndrome and following

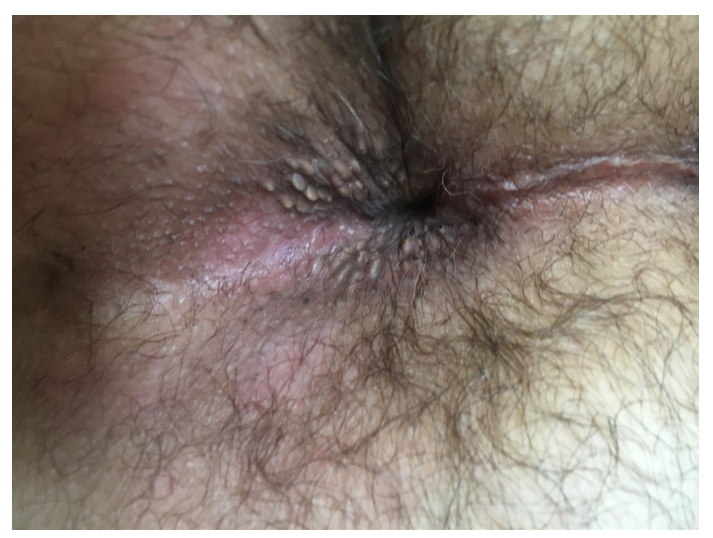

Figure 1 Multiple perianal papules with plugged follicular orifices consistent with perianal comedones.

\section{Learning points}

- Perianal comedones are a rare entity, with only three previously documented cases.

- While there is a postulated association with chronic topical steroid use and pruritus ani, our case report supports the notion that this condition can be asymptomatic and may not be associated with any medical treatment.

- Clinicians should be aware of the potential for comedones to occur in the perianal region, and reassure patients of their benignity and lack of association with systemic disease.

occupational exposure to coal tar, oil and dioxin. ${ }^{12}$ While the distribution of comedones in these conditions is varied, none are associated with comedones occurring in the perianal region.

According to the literature, there are only three previous case reports of perianal comedones. The earliest report inferred an association of perianal comedones with chronic topical fluorinated steroid application to the anus, which was prescribed for pruritus secondary to chronic diarrhoea. ${ }^{3}$ The authors suggested that topical steroids can render the follicular epithelium more responsive to the comedogenic effects of sebum in addition to having an occlusive effect. ${ }^{3}$ A letter in response to this report questioned the association of perianal comedones and topical steroids, supported by anecdotes of patients presenting with anal comedones associated with pruritus, without previous topical steroid use. ${ }^{4}$ In the latter two case reports, perianal comedones were asymptomatic incidental findings and not associated with use of topical steroids, as noted in our patient. ${ }^{12}$ The occlusive conditions of the perianal region together with the potential for this region to be more prone to irritant dermatitis are possible explanations for the development of comedones in this unusual location. ${ }^{1}$

The documented rarity of perianal comedones in the literature may be secondary to underreporting both because of the potential for this entity to be asymptomatic and because of the infrequent examination of the perianal region as part of a complete skin examination. ${ }^{12}$ However, one would expect perianal comedones to be noted as an incidental finding by doctors who regularly perform endoscopies and rectal examinations. Clinicians should, therefore, be aware of this rare but seemingly benign finding. 
Images in...

Contributors AD: conception, planning and writing of the case report. LM: writing and proofreading of the case report. LS: supervision and proofreading.

Funding The authors have not declared a specific grant for this research from any funding agency in the public, commercial or not-for-profit sectors.

Competing interests None declared.

Patient consent for publication Obtained.

Provenance and peer review Not commissioned; externally peer reviewed.

\section{REFERENCES}

1 Powell PR, Garza-Chapa JI, Susa JS, et al. Perianal Comedones: a rare incidental finding. Case Rep Dermatol Med 2017;2017:1-4.

2 Lurati MCR, Hohl D. Multiple Comedonelike lesions encircling the anal Orifice-Quiz case. Arch Dermatol 2009;145:1447-52.

3 Oliet EJ, Estes SA. Perianal Comedones associated with chronic topical fluorinated steroid use. J Am Acad Dermatol 1982;7:405-7.

4 Silver SE. Perianal Comedones and topical corticosteroids. J Am Acad Dermatol 1983;8:912

Copyright 2020 BMJ Publishing Group. All rights reserved. For permission to reuse any of this content visit

https://www.bmj.com/company/products-services/rights-and-licensing/permissions/

BMJ Case Report Fellows may re-use this article for personal use and teaching without any further permission.

Become a Fellow of BMJ Case Reports today and you can:

- Submit as many cases as you like

Enjoy fast sympathetic peer review and rapid publication of accepted articles

- Access all the published articles

- Re-use any of the published material for personal use and teaching without further permission

Customer Service

If you have any further queries about your subscription, please contact our customer services team on +44 (0) 2071111105 or via email at support@bmj.com.

Visit casereports.bmj.com for more articles like this and to become a Fellow 